\title{
Escrita literária, leitura filosófica: \\ as Canções sem metro, de Raul Pompeia
}
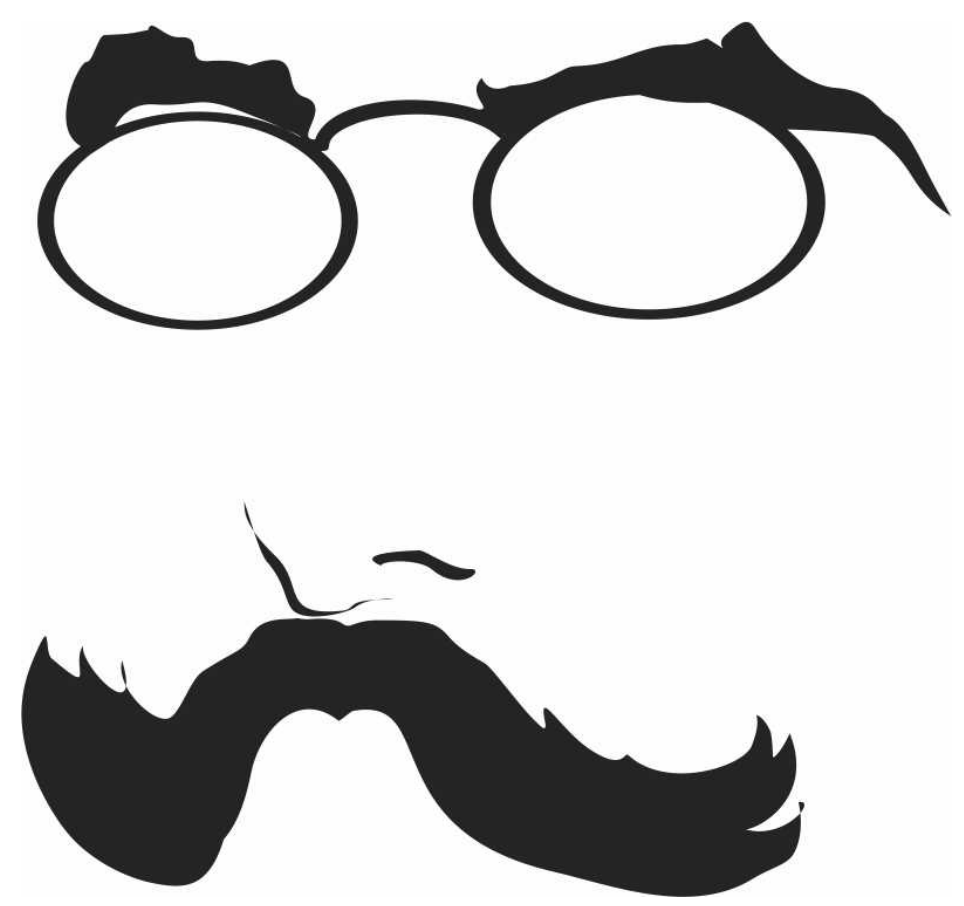

Raul Pompeia, desenho de

Eduardo Warpechowski, 2021.

\section{Marconi Severo}

Doutorando em Ciências Sociais da Universidade Federal de Santa Maria (UFSM). marconisevero@hotmail.com 


\section{Escrita literária, leitura filosófica: as Canções sem metro, de Raul Pompeia}

Literary writing, philosophical reading: the Canções sem metro, by Raul Pompeia

\section{Marconi Severo}

\section{RESUMO}

Este texto é dedicado à análise de Canções sem metro, de Raul Pompeia. Sustento aqui dois argumentos que, de certa forma, estendem-se a todo o legado artístico-literário do escritor: em primeiro lugar, abordo o pessimismo frequentemente atribuído a ele, e supostamente realçado em tal obra, o que acredito tratar-se de uma interpretação equivocada; e, em segundo lugar, entendo que, para o autor, o ser humano é essencialmente mau, fato que coloca em dúvida tanto os usos que a humanidade faz dos recursos naturais, quanto as relações estabelecidas entre os homens. Por outro lado, e apesar de sua concepção negativa da natureza humana, argumento que Pompeia não deixa de crer na possibilidade de uma sociedade melhor, conforme expressa por meio da ideia de "progresso relativo" e do ideal de "esperança".

PALAVRAS-CHAVE: Canções sem metro; Filosofia; Raul Pompeia.

\begin{abstract}
This text is dedicated to the analysis of the work Canções sem metro, by Raul Pompeia. I defend here three arguments which, in a certain way, extend to the entire artistic-literary legacy of the writer: firstly, I address the pessimism often attributed to him, and supposedly highlighted in Canções, which I believe is a mistaken interpretation; Secondly, I defend that, for Pompeia, the human being is essentially bad, a fact that puts in doubt both the uses that humanity makes of natural resources, as well as the relations established between men. On the other hand, and despite his negative conception of human nature, Pompeia does not fail to believe in the possibility of a better society, which he expresses through the idea of "relative progress" and the ideal of "hope".
\end{abstract}

KEYWORDS: Canções sem metro; Philosophy; Raul Pompeia.

Raul Pompeia manifestou-se no Ateneu um psicólogo da raça. Analista feliz, claro, transparente, nenhuma das qualidades indispensáveis parecem-lhe faltar para torná-lo um Stendhal moderno; o que quer dizer que, além de um artista, nesse escritor existe um filósofo, um pensador.

Araripe Júnior ${ }^{1}$

A consagração de Raul d'Ávila Pompeia (1863-1895) junto aos grandes nomes da literatura brasileira deve-se, sobretudo, ao seu romance intitulado $O$

\footnotetext{
${ }^{1}$ ARARIPE JÚNIOR, Tristão de Alencar. O Ateneu e o romance psicológico. Novidades, ano II, n. 267, Rio de Janeiro, 12 dez. 1888.
} 
Ateneu. Sua produção intelectual, contudo, vai muito além desse romance: Pompeia foi também um cronista perspicaz - Eloy Pontes, seu primeiro biógrafo, chegou a afirmar que "o jornalismo era seu verdadeiro destino" ${ }^{-}$, assim como contista, ensaísta e novelista. Em meio às suas produções figuram suas Canções sem metro (muito provavelmente sua segunda obra mais conhecida). Publicadas de forma avulsa desde 1883, as "canções" só seriam compiladas postumamente, em 1900. Para Silva³, essa é uma obra "cosmogônica", resultado de um trabalho que Pompeia "acalentou durante toda a sua vida de artista", tal como já havia dito Eloy Pontes", segundo o qual as Canções sem metro "foram compostas entre 1882-1883, revistas de 'fond en comble', em 18851886, e, de novo, escritas em 1893-1894", mas nunca compiladas pelo simples fato de que o seu autor "regressava sempre ao trabalho feito. O gênio é uma grande paciência", o que comprova, sob o preço de contrariar a crítica de todo um século, que para o escritor a sua principal produção artística não era $O$ Ateneu, e sim suas Canções sem metro.

Aliás, essa mesma crítica secular, no duplo sentido do termo, é a principal responsável pela constituição de um imaginário mais ou menos difundido que não hesita em associar Raul Pompeia à figura de um escritor pessimista, triste e, por vezes, mórbido. Sustento, entretanto, que tal concepção é equivocada e que, nesse sentido, a análise de Canções sem metro inegavelmente contribui para uma melhor compreensão do legado artísticoliterário, bem como da personalidade de Pompeia. Daí a necessidade de apreender as influências exercidas sobre o escritor como condição necessária para compreender como ele próprio concebia sua obra, o que equivale a problematizar como o escritor esperava que fosse sua recepção artística. Para tanto, apoio-me em duas fontes analíticas: de um lado, o programa especificado em suas crônicas, especialmente àquelas publicadas na seção "Pandora" do jornal Gazeta de Notícias, ao longo de 1888; de outro, as contribuições filosóficas contidas em Canções sem metro, ou seja, aquilo que proporcionaria ao leitor, conforme escreveu Pompeia em crônica sobre as poesias de Olavo Bilac, o "benefício moral da leitura". ${ }^{5}$

É nessa perspectiva que tomo o problema já proposto por Silva ${ }^{6}$ - e retomado por ele em texto publicado no ano seguinte ${ }^{7}-$, quando sugere que existe uma ausência de interpretações sobre o conjunto dessa obra, isto é, sobre o seu viés artístico e filosófico. ${ }^{8}$ Para ele, efetuar uma análise das canções

\footnotetext{
2 PONTES, Eloy. Raul Pompeia, sua vida, seu tempo, sua obra. Revista Brasileira, n. 5, Rio de Janeiro, dez. 1934, p. 187.

${ }^{3}$ Ver SILVA, Marciano Lopes e. A Pandora de Raul Pompeia. Acta Scientiarum: Human and Social Sciences, v. 24, n. 1, Maringá, jan.-dez. 2002, p. 36.

${ }^{4}$ PONTES, Eloy, op. cit., p. 194.

${ }^{5}$ POMPEIA, Raul. Pandora: poesias de Olavo Bilac. Gazeta de Notícias, ano XIV, n. 281, Rio de Janeiro, 8 out. 1888.

${ }^{6}$ Ver SILVA, Marciano Lopes e. A recepção crítica das Canções sem metro, de Raul Pompeia. Acta Scientiarum, op. cit.

${ }^{7}$ Ver idem, Decadência das civilizações e memória dos ideais: a filosofia da história na obra de Raul Pompéia. Acta Scientiarum: Human and Social Sciences, v. 25, n. 2, Maringá, jul.-dez. 2003.

${ }^{8}$ Em outro texto, Silva ressaltou que "podemos observar não somente uma preocupação moralizadora como também um apelo revolucionário" em Canções sem metro, o que o levou a concluir que nessa obra a "dimensão filosófica se sobrepõe à literária". Idem, Raul Pompeia: impasses de um formalista avant la lettre. Acta Scientiarum: Human and Social Sciences, v. 24, n. 1, op. cit., p. 26. Em minha opinião, não se trata de uma sobreposição, mas sim uma justaposição de duas dimensões distintas que se complementam; quanto
} 
como um todo, além contribuir "para uma compreensão holística da obra de Raul Pompeia", também é importante "para uma reflexão sobre as relações entre literatura e sociedade".${ }^{9}$ Daí a opção pelos pressupostos metodológicos típicos da análise sociológica. Acredito que por intermédio deles seja possível superar aquilo que Silva chamou de "postura positivista presente nos estudos preocupados com a inserção estilística das obras nas escolas literárias", superação que só se dá mediante a "análise da significação dos temas e das figuras juntamente com o estudo da intertextualidade e da interdiscursividade"10 que transcenda a mera literariedade, conforme o programa dos formalistas russos. Digo isso por oposição às práticas dos que costumam tomar isoladamente uma parte da obra sem conectá-la com o todo, do que resultam interpretações como as de Sandanello ${ }^{11}$, para quem os poemas em prosa da primeira parte do livro são repetitivos, cansativos e vazios (o mesmo ocorre com aqueles que utilizam $O$ Ateneu como padrão analítico para o estudo da produção de Pompeia, fato que explica a tão recorrente classificação do escritor ora como impressionista, ora como realista, além do hábito de atribuir-lhe a contragosto o caráter de autor de um romance autobiográfico - interpretação que ele repudiava com veemência).

A fim de que fosse possível empreender este estudo sem que houvesse o perigo de recair nos clássicos lugares-comuns das interpretações sobre outras interpretações, sempre que possível lancei mão de fontes originais, tais como contos, crônicas, livros etc. ${ }^{12}$ A cautela com as versões das quais fiz uso se justifica duplamente: primeiro, porque permite reconstituir o cenário social, político e cultural brasileiro à época e de acordo com a concepção do próprio escritor (especialmente através de suas crônicas); em segundo lugar, porque a análise desse material possibilita uma melhor compreensão de como Raul Pompeia concebia sua obra e de como ele esperava que ela fosse recebida e interpretada. (Por isso podemos conceber a literatura como uma forma de interação de um autor com sua sociedade e época, do que decorre a impossibilidade de asserções ao estilo "estava à frente de seu tempo").

Ao contrário de certas teorias que veem a literatura como uma espécie de "espelho" social (pois refletiria, aquém de uma interação, isto é, desconsiderada a refração, a realidade da sociedade de onde se origina), procuro analisá-la tomando por base sua capacidade de expressar, constituir e reconstituir visões de mundo. O interesse pelas produções literárias - dentro do universo de bens culturais - pauta-se na capacidade inerente às obras dessa natureza de abordar inúmeras temáticas, bem como na maneira como essa abordagem

ao "apelo revolucionário", penso ser um exagero, pois nenhuma canção (ou seu conjunto) permite sustentar tal afirmativa.

${ }^{9}$ SILVA, Marciano Lopes e. A recepção crítica das Canções sem metro, de Raul Pompeia. Acta Scientiarum: Human and Social Sciences, v. 24, n. 1, op. cit., p. 18.

${ }^{10}$ Idem.

11 Ver SANDANELLO, Francisco B. Raul Pompeia, leitor de Baudelaire: da teoria das correspondências às canções sem metro. Opiniães, v. 2, n. 3, São Paulo, jan.-jun. 2011.

12 Agradeço à equipe responsável pela disponibilização do acervo digital da Biblioteca Nacional, cujo material pesquisado foi indispensável para a elaboração deste artigo. Com relação aos contos citados, salvo os casos referenciados, os demais são oriundos da Biblioteca Digital de Literaturas de Língua Portuguesa, mantida pela Universidade Federal de Santa Catarina. Contudo, impõem-se observações: (1) embora nesta plataforma conste o título "Contos completos", em pesquisa junto ao acervo da Biblioteca Nacional encontrei alguns que não figuram na mencionada coletânea; (2) em razão da disponibilização em formato digital, os contos oriundos desta fonte estão sem data (s./d.) e sem indicação de páginas (s./p.). 
pode ser realizada. Tal reflexão levou Bourdieu a salientar que aquilo que é dito por meio da literatura poderia ser praticamente impossível de ser dito através da linguagem científica, uma vez que ela é capaz de "concentrar e de condensar na singularidade concreta de uma figura sensível e de uma aventura individual", que funcionaria "ao mesmo tempo como metáfora e como metonímia", toda "a complexidade de uma estrutura e de uma história", tarefa "que a análise científica precisa desdobrar e estender laboriosamente"13, caso queira se aproximar, sob esse aspecto, da obra literária.

Embora seja consensual entre os pesquisadores que a Sociologia da Literatura - ou "crítica sociológica", para Souza ${ }^{14}$ - ainda não possua um programa específico (tal como se verifica com a Sociologia da Religião, da Educação etc.), parece haver algum entendimento de que a obra literária não deve ser considerada como um simples "objeto" de análise. Ora, se literatura e sociedade estão "mutuamente referidas em uma relação significativa", tal como preconizado por Botelho e Hoelz ${ }^{15}$, logo, a análise de uma obra literária não só pode como deve ser vista igualmente como um objeto multifocal, uma vez que envolve escritores, editores, leitores, mercado e consumo de bens culturais. É sob esse viés que reconheço o potencial de condensação e transmissão de conhecimentos pela via da literatura, como exemplificado em Canções sem metro.

Originalmente este texto compunha-se de duas grandes seções que visavam analisar as Canções, a primeira focada na análise geral da obra e sua filosofia tácita, e a outra, na segunda parte do livro, a fim de melhor apreender o estilo literário de Raul Pompeia, ou seja, aquilo que eu chamei de circularidade interna e chiaroscuro (técnicas que possibilitariam, sob pena de incompreensão crítica, a leitura e a interpretação filosófica "do todo"). Todavia, por razões meramente textuais, vi-me obrigado a reestruturá-lo. ${ }^{16} \mathrm{Tem}-\mathrm{se}$, assim, que a estrutura do artigo se delineia da seguinte forma: em um primeiro momento, elaboro algumas reflexões acerca da concepção e a publicação (avulsa e compilada) das Canções; na sequência, analiso a estrutura geral da obra tomando como base a edição de 1900 (contrastando-a com a de 2013); por fim, precedendo as considerações finais, discuto o suposto pessimismo de Raul Pompeia, procurando entendê-lo de acordo com sua concepção filosófica da natureza humana (que, diga-se de passagem, é muito semelhante àquela adotada por Dostoiévski).

\footnotetext{
${ }^{13}$ BOURDIEU, Pierre. As regras da arte: gênese e estrutura do campo literário. 2. ed. 1. reimpr. São Paulo: Companhia das Letras, 2010, p. 39.

14 SOUZA, Roberto A. Q. Teoria da literatura. 10. ed. 3. reimpr. São Paulo: Ática, 2010.

${ }^{15}$ BOTELHO, André e HOELZ, Maurício. Sociologias da literatura: do reflexo à reflexividade. Tempo Social, v. 28, n. 3, São Paulo, set.-dez. 2016, p. 280.

${ }^{16}$ Razão pela qual a segunda parte do livro, intitulada "Amar", foi analisada separadamente. Quanto às técnicas estilísticas, ou melhor, ao estilo literário de Raul Pompeia (tema de uma pesquisa ainda em andamento), basta dizer, por ora, que a circularidade interna consiste na composição de cada canção seguindo uma estrutura de introdução-desenvolvimento-conclusão, tal como ocorre com as partes do livro e com o próprio livro como um todo (o que permite sua leitura hermenêutica); já o chiaroscuro literariamente empregado por Pompeia, à lá Caravaggio (1571-1610), implica um rigoroso emprego de substantivos e adjetivos para descrever um cenário sombrio para que, com isso, uma única mensagem transpareça como a "luz" (o ideal de "esperança").
} 
As Canções sem metro, ao lado de O Ateneu, figuram entre as produções literárias mais conhecidas de Raul Pompeia. Publicadas aleatoriamente em folhetins desde 1883 (quando o escritor possuía cerca de 20 anos), só foram compiladas postumamente, em 1900. Desde então, surgiram várias reedições, variando em número de páginas e adereços artísticos (imagens, diagramação, impressão etc.). Prezando pela originalidade textual, este trabalho pauta-se precisamente nessa primeira edição póstuma. Mas isso quer dizer que ela é a melhor edição já compilada? Não necessariamente. Como sua escolha se deve sobretudo ao seu valor histórico, utilizei, para fins de leitura comparada e complementar, a edição organizada por Gilberto Araújo ${ }^{17}$, que é, a meu ver, a melhor e mais completa versão atualmente disponível. A exemplo de Silva ${ }^{18}$, também Araújo se refere a Raul Pompeia como um vanguardista brasileiro no gênero do poema em prosa, ou prosa poética, conforme expressão de BragaPinto $(2014)^{19}$, embora ambos concordem que o escritor tem sido lembrado apenas por referência a $O$ Ateneu, do que resulta, segundo Araújo, a insustentável caracterização de Raul Pompeia como "autor de um livro só" 20 -, fato que, obviamente, contribui para obnubilar suas demais produções. Daí que Silva frise que a incompreensão crítica sobre o legado de Raul Pompeia é tão renitente que não seria errado afirmar que ele "se encontra entre os que têm sido incompreendidos ou injustiçados" ${ }^{21}$ pela crítica especializada.

A prática de publicação em folhetins seguida, conforme o caso, de posterior compilação textual, deve ser vista como uma atividade corriqueira naquele momento: para me restringir à produção de Pompeia, pode-se dizer que o mesmo processo ocorreu com $O$ Ateneu, que, publicado originalmente em folhetim, foi compilado ainda no mesmo ano, em 1888.22 Por outro lado, é importante salientar que a publicação em folhetim, para Pompeia, não decorria de uma busca de aprovação dos seus textos perante a "opinião pública". Tal prática era uma alternativa dentro de um universo de possibilidades frente aos padrões de gosto e comercialização de bens culturais e literários da época. Sobre esse aspecto, é elucidativo citar o próprio autor, em crônica intitulada "Glória latente": "Escrever: formular, comunicar. Mas que pretendemos dos outros? Aplauso? A arte que vive do aplauso rebaixa-se, prostitui-se; as chamas ardem para cima". E acrescenta: "Critério? A arte que não tem apoio na

\footnotetext{
17 Ver ARAÚJO, Gilberto. Introdução. In: POMPEIA, Raul. Canções sem metro. Organização, introdução e notas de Gilberto Araújo. Campinas: Editora da Unicamp, 2013.

${ }^{18} \mathrm{Cf}$. os artigos de SILVA, Marciano Lopes e. citados anteriormente.

${ }^{19}$ BRAGA-PINTO, César. The Honor of the abolitionist and the shamefulness of slavery. Luso-Brazilian Review, v. 51, n. 2, Madison, jul.-dez. 2014. Para uma abordagem sobre esse gênero literário, nascido na primeira metade do século XIX na França, ver KEMPINSKA, Olga. "A alegria é una": O poema em prosa e a poética da ironia. Caligrama: Revista de Estudos Românicos, v. 24, n. 3, Belo Horizonte, set.-dez. 2019. Chama a atenção, contudo, que a autora ignora a contribuição de Paul Pierson, concentrando-se, tal como faz Sandanello (citado na nota 11) em Baudelaire. Também é digno de nota que não há nenhuma menção, para o caso brasileiro, a Raul Pompeia nem a Cruz e Souza (1861-1898), com seu Missal.

${ }^{20}$ ARAÚJO, Gilberto, op. cit., p. 11.

${ }^{21}$ SILVA, Marciano Lopes e. Por uma revisão crítica da obra de Raul Pompeia. Acta Scientiarum: Human and Social Sciences, v. 23, Maringá, jan.-dez. 2001, p. 109.

${ }^{22}$ Já no final de maio anunciava a Gazeta de Notícias: “Está impresso em volume o romance de Raul Pompeia, que tanto agradou quando publicado nesta folha. Vende-se em nosso escritório a $2 \$ 000 "$ ". Gazeta de Notícias, ano XIV, n. 150, 30 maio 1888.
} 
convicção da própria força sucumbe; a hesitação atrofia e anula; a arte forte cresce de si mesmo, organicamente". ${ }^{23}$

Pompeia não possuía uma única filiação estilística (romantismo, naturalismo, simbolismo); o seu programa era tão somente a produção de obras que, independentemente do estilo, seriam em primeiro lugar artísticas, contassem ou não com a aprovação do público leitor. ${ }^{24}$ Sobre isso, é interessante mencionar uma das conclusões de Silva, baseado no seu estudo da seção "Pandora": "Raul Pompeia misturava diversos gêneros em busca de uma nova forma expressiva - daí a sua singularidade e importância para a renovação da Literatura Brasileira no final do século XIX". ${ }^{25}$ Para este estudioso, a melhor classificação estilística que pode ser atribuída a Raul Pompeia, mesmo consciente de sua limitação e inaplicabilidade a algumas de suas obras, recairia em algo como "uma mundividência romântica em crise" caracterizada por uma visão desencantada, beirando o pessimismo, mas sem por isso ser classificada como simbolista ou decadentista. ${ }^{26}$ Sem nos atermos a esses caminhos tortuosos das classificações estilísticas, o que nos interessa reter aqui é que Raul Pompeia transitou - e com relativa desenvoltura - em terrenos que vão do realismo ao simbolismo, do romantismo ao impressionismo, sem, contudo, se fixar em nenhuma dessas correntes. Seja como for, ao contrário de Silva, penso que, de maneira geral, em quaisquer de suas obras de cunho estritamente literário (excluindo-se, portanto, suas crônicas e escritos políticos), predomina uma preocupação com o compromisso da arte pela arte, à margem do pertencimento a qualquer escola.

\section{A estrutura da obra}

Quanto à edição de Canções sem metro aqui analisada ${ }^{27}$, a despeito de se tratar de uma compilação, não há nela, como costumeiramente se observa, uma introdução que forneça ao leitor maiores informações sobre sua publicação. Essa falta, no entanto, é corrigida na metade do livro, onde consta uma nota explicativa que é igualmente uma homenagem do editor (e amigo) ao autor. Sob o título de "12 de Abril" (dia de nascimento de Raul Pompeia), João Andréa explica que essa data lhe pareceu a melhor para dar publicidade à obra do "glorioso artista", missão que lhe foi delegada pela mãe do escritor, segundo os escritos reunidos pelo filho. De acordo com o editor, tal versão corresponde "à fiel reprodução dos originais": "abroquelado, pois, contra a possível suspeita de uma temerária colaboração na obra de Raul Pompeia, assino esta folha, assim destacada, para que nem mesmo se dê a intromissão do nome de um amigo neste livro de arte". ${ }^{28}$

\footnotetext{
${ }^{23}$ POMPEIA, Raul. Pandora: Glória latente. Gazeta de Notícias, ano XIV, n. 261, 18 set. 1888. Para Silva, este texto constitui um conto e não uma crônica, apesar de ele ser um "metatexto fundamental para a compreensão dos valores estéticos de Raul Pompeia e para a compreensão do projeto artístico que fundamentou as Canções sem metro". SILVA, Marciano Lopes e. A Pandora de Raul Pompeia, op. cit., p. 36.

${ }^{24}$ Este foi, inclusive, o tema de uma das palestras do Prof. Cláudio, alter ego de Raul Pompeia em O Ateneu.

${ }^{25}$ SILVA, Marciano Lopes e. A Pandora de Raul Pompeia, op. cit., p. 37.

${ }^{26}$ Idem, Por uma revisão crítica da obra de Raul Pompeia. op., cit., p. 118.

${ }_{27}$ POMPEIA, Raul. Canções sem metro. Rio de Janeiro: Typographia Aldina, 1900.

${ }^{28}$ ANDRÉA, João. 12 de abril. In: POMPEIA, Raul. Canções sem metro, op. cit., p. 33.
} 
Assinale-se que a edição de 1900 é significativamente menor do que a organizada por Araújo em 2013, porque muitas canções não foram publicadas na primeira compilação. Isso provavelmente se deve - e aqui, infelizmente, não poderemos ir além de uma conjectura - a duas razões: ou o editor fez uma seleção arbitrária das canções (o que é pouco provável) ou, de fato, publicou a versão organizada pelo próprio escritor antes de suicidar-se. Em defesa desta última hipótese, o editorial da Gazeta da Tarde, de 26 de dezembro de 1895, ou seja, um dia após o suicídio de Raul Pompeia e cinco anos antes da edição de 1900, traz a seguinte nota: “Os Srs. Alves \& Cia. vão publicar brevemente um livro de Raul Pompeia, denominado Canções sem metro, cujo manuscrito entregou, três horas antes de suicidar-se, à sua desolada mãe". ${ }^{29}$ Daí o valor histórico e hermenêutico da publicação original: idealizada pelo próprio escritor como sua versão final, ela permite supor como Raul Pompeia gostaria que o público a conhecesse.

O livro original das Canções sem metro, apresentado ao leitor por meio de um prólogo - citação, no original em francês, de Métrica natural da linguagem, de Paul Pierson (1851-1880) -, estrutura-se em cinco partes distintas: I Vibrações, II - Amar, III - Ventre, IV - Vaidades e V - Infinito. Na primeira parte encontra-se uma "canção" (a maior de todas) que, após breve introdução, se subdivide em vários subtítulos que associam uma cor a um sentimento ("Verde, esperança"; "Amarelo, desespero" etc.), e finaliza com dois trechos distintos, em tom conclusivo: "o incolor diáfano do vidro"30 e a "coloração indistinta dos sentimentos, nas almas deformadas". ${ }^{31} \mathrm{Na}$ segunda parte, intitulada "Amar", encontramos um quantitativo maior de "canções": são cinco temas diferentes, os quatro primeiros correspondentes às estações do ano (Inverno, Primavera, Verão e Outono, respectivamente), arrematados por uma reflexão com o sugestivo título de "Ilusão renitente". A terceira parte, "Ventre", é constituída por oito "canções", mais a mencionada nota explicativa do editor. A quarta e a quinta partes, "Vaidades" e "Infinito", enfeixam nove canções cada uma. Entretanto, na última, figura uma "Conclusão" que serve tanto para a quinta parte do livro quanto para a obra como um todo, motivo pelo qual a considero à parte. Tem-se, então, que a primeira edição de Canções sem metro é formada por um prólogo, uma nota explicativa do editor e cinco partes que somam trinta e duas "canções". Desse total, somente sete não possuem epígrafe (duas em "Ventre": "Comércio" e "Ventre"; duas em "Vaidades": "História de amor" e "Revoluções"; três em “Infinito": “Ontem", “Hoje” e “Solução").

Em que pese não ser comum entre os críticos de obras artísticas, especialmente das obras literárias - assim como também não é costumeiro entre aqueles que tomam a literatura como "objeto" de investigação -, observar a importância de recursos estilísticos empregados pelo autor, tais como imagens e epígrafes, afora idiomas, creio que esse material é indispensável para a análise da produção literária. É com base nesses recursos textuais que podemos mapear as influências e intenções estilísticas do autor (ou editor). Em se tratando de Raul Pompeia, por exemplo, é possível citar dois casos paradigmáti-

\footnotetext{
${ }^{29}$ Gazeta da Tarde, Editorial, ano XVI, n. 354, Rio de Janeiro, 26 dez. 1895.

${ }^{30}$ POMPEIA, Raul. Canções sem metro. op. cit., p. 14.

${ }^{31}$ Idem, ibidem, p. 15.
} 
cos. A publicação de $O$ Ateneu $u^{32}$ em volume único, em 1888, não conta com as gravuras elaboradas pelo próprio autor, reconhecido entre os seus pares por sua grande habilidade artística com gravuras e desenhos; porém, na segunda edição, datada de $1905^{33}$, foi incrementado ao livro um total de quarenta e três desenhos que permitem compreender mais a fundo como Raul Pompeia imaginava o ambiente do internato escolar por ele criado.

Por essa razão, já na introdução Araújo sublinha que o "imbricamento/literário pictórico e o gráfico/editorial" repercutiu sobremaneira na obra de Raul Pompeia, uma vez que ele era "exímio desenhista", a tal ponto que, além de ilustrar os seus próprios textos, "também foi capista e ilustrador de livros alheios"34. Rodrigo Octávio, amigo de Raul Pompeia (cujo livro Festas nacionais foi prefaciado com um polêmico texto político do escritor), ressaltou que "era notória a aptidão do ilustre moço para a pintura e escultura. Alguns pequenos trabalhos deixou, cabeças de criança, troncos de mulher, frutos apenas de sua intuição, alheios completamente aos ensinamentos do mestre, que não teve", e mais, que "nos últimos tempos ele falou-me várias vezes numa projetada viagem à Itália e ‘de lá voltarei escultor, dizia ele. Ainda é tempo de aprender'”. 35

No caso de Canções sem metro, as epígrafes empregadas cumprem um papel semelhante, ou seja, possibilitam mapear as influências exercidas sobre Pompeia por outros autores, além de auxiliarem na compreensão do universo artístico-literário no qual ele se situava. Com relação a elas, observou Domício da Gama, que, "ao mesmo tempo" em que "revia as provas de uma edição das Canções sem metro", Raul Pompeia "procurava ainda epígrafes, 'porque com epígrafes', dizia ele, 'pode-se concentrar num livro toda a poesia humana'”, emendando que o escritor, porém, "não encontrou sem dúvida todas as de que carecia, pois que em oito anos o livro não ficou pronto". ${ }^{36}$ Se o próprio escritor devotou tamanha atenção às epígrafes, como negligenciá-las?

Embora não exista nenhuma gravura na compilação original das Canções sem metro, há uma abundância de epígrafes. Por meio delas percebe-se que Raul Pompeia tinha noções, no todo ou em parte, de pelo menos seis idiomas. São eles, por ordem de incidência em número de epígrafes: francês (nove), latim (sete), italiano (cinco), inglês (duas), espanhol (duas) e catalão (uma). Isso explicita dois fatos igualmente significativos: de um lado, a forte influência do francês como língua utilizada internacionalmente à época (como é hoje o inglês); de outro, que o latim, atualmente em desuso, figurava ainda com força entre as classes dominantes de então. Aliás, sob este aspecto, não devemos particularizar Raul Pompeia, mas antes tomá-lo como um homem de sua classe e de sua época.

A passagem por colégios de elite (Colégio Abílio e Pedro II), com posterior formação em Direito (iniciada em São Paulo e concluída em Recife), nada mais era do que uma consequência de sua condição social privilegiada: a

\footnotetext{
32 Idem, O Ateneu: crônica de saudades. Rio de Janeiro: Typographia da Gazeta de Notícias, 1888.

${ }^{33}$ Idem, ibidem, 2. ed. Rio de Janeiro: Livraria Francisco Alves \& Cia., 1905 (versão definitiva, conforme os originais e os desenhos deixados pelo autor).

${ }^{34}$ ARAÚJO, Gilberto. op. cit., p. 15.

${ }_{35}$ OCTÁVIO, Rodrigo. Raul Pompeia: saudades e evocações. Revista Brasileira, ano II, tomo V, Rio de Janeiro, 1896, p. 110.

${ }^{36}$ GAMA, Domício [pseudônimo de Domício A. Forneiro]. Discurso proferido na Academia Brasileira de Letras. A República, ano XV, n. 160, Rio de Janeiro, 22 jul. 1900.
} 
aprendizagem de idiomas como francês e latim, por exemplo, mais do que uma exigência institucional dos estabelecimentos de ensino que frequentou, era sinal de distinção social. De resto, a formação intelectual nesse período pautava-se, em larga medida, em materiais importados. Entende-se assim o porquê de o mercado editorial de então investir pouco em traduções para o vernáculo, já que ele era relativamente restrito às mesmas classes que poderiam acessar os textos em sua língua original ${ }^{37}$ (é emblemático que a epígrafe de "Tormenta e bonança", presente na última parte do livro, consista em uma tradução de Heine - originalmente em alemão - para o francês, idioma lido e citado por Raul Pompeia).

Não nos esqueçamos, paralelamente, do uso arraigado, naquele tempo, de citações textuais de palavras estranhas ao nosso idioma (grande parte delas atualmente incorporada à língua portuguesa). É conveniente ainda explorar as informações referentes à autoria das epígrafes, o que equivale a apreender a influência, direta ou indireta, exercida por outras pessoas sobre Raul Pompeia. Os autores citados nas epígrafes em francês, além da tradução mencionada anteriormente e do prólogo, são, na sua ampla maioria, de coetâneos do escritor: Charles Baudelaire (1821-1867), Auguste Brizeux (1803-1858), Victor Hugo (1802-1885), Pierre-Joseph Proudhon (1809-1865) e Molière (1622-1673). Em latim predominam as citações da Bíblia (três em Gênesis, uma em Salmos), sem contar as de alguns autores de procedência incerta. ${ }^{38} \mathrm{Em}$ italiano as citações são de Dante Alighieri (1265-1321), com três epígrafes, e Giacomo Leopardi (1798-1837), com duas. As duas epígrafes em inglês correspondem a Thomas Nashe (1567-1601) e a William Shakespeare (1564-1616). Por fim, as duas em espanhol são de José Espronceda y Delgado (1808-1842), a que se soma outra em catalão, de Jacinto Verdaguer y Santaló (1845-1902). Se considerarmos os idiomas e os autores citados, bem como nuances estilísticas do escritor, nada impede de atribuirmos a ele o adjetivo de intelectual cosmopolita (o que explica sua desenvoltura ao percorrer diversas correntes artísticoliterárias).

Contudo, a despeito de não ser citado nem uma única vez, entendo que a maior influência na composição de Canções sem metro, pelo menos no que concerne ao seu conteúdo, deve-se ao húngaro Max Nordau (1849-1923). A propósito, é curioso que quase nenhum dos analistas brasileiros de Raul Pompeia tenha dado a merecida atenção a esse aspecto de sua obra (nem mesmo Marciano Silva, um dos últimos grandes estudiosos de Pompeia); o único pesquisador, que eu saiba, a identificar tal influência foi Braga-Pinto, que estudou minuciosamente o legado de Raul Pompeia.

\footnotetext{
${ }^{37}$ De acordo com José Murilo de Carvalho, o "elemento poderoso de unificação ideológica da política imperial foi a educação superior", "porque quase toda a elite possuía estudos superiores, o que acontecia com pouca gente fora dela: a elite era uma ilha de letrados num mar de analfabetos". CARVALHO, José Murilo de. A construção da ordem e Teatro de sombras. 2. ed. Rio de Janeiro: Editora UFRJ/Relume-Dumará, 1996, p. 55. Apesar de Raul Pompeia ser um republicano convicto, pertencia à mesma classe dos "letrados". 38 Tudo leva a crer que sejam os seguintes os autores das epígrafes correspondentes às "canções" mencionadas: "História de Amor", de Bernardo de Claraval (1090-1153); "Veritas", de Jacopone da Todi (1236-1306), e "Conclusão", de Alain de Lille (1128-1202). Ver SOUZA, Francisco Edi de Oliveira. Uma leitura de Canções sem Metro: a partir do diálogo com a obra de Baudelaire. Fortaleza: Imprensa Universitária, 2014.
} 
Em crônica intitulada "Os 'paradoxos' de Max Nordau", de 6 de agosto de 1888, Pompeia discorre acerca de suas impressões sobre os livros Mentiras convencionais e Paradoxos (ambos desse escritor). Para ele, essas obras são de um "azedume pessimista da crítica", com uma base argumentativa assentada sobre "o desgosto dos erros artificiais que concorrem para tormento da humanidade com as contingências desagradáveis da ordem natural", ou seja, sobre os usos indevidos que a humanidade faz dos seus progressos científicos e industriais, sem que isso erradique a possibilidade de uma "esperançada da corrigenda". Para Pompeia, Nordau estuda as mentiras religiosa, matrimonial, econômica, política e "toda a hipocrisia social reinante" com o intuito não de "construir o mundo feliz de Pangloss", mas sim "para que a existência mais se conforme com a relatividade agridoce, que é a partilha comum do ser" ${ }^{39}$

Nordau fala de "relatividade agridoce"; Pompeia, de "progresso relativo". Ambos não concebem saídas revolucionárias aos problemas por eles reconhecidos, e sim medidas que poderíamos chamar de reformistas ("corrigendas"). É por isso que Pompeia conclui sua crônica afirmando que, apesar do pessimismo atribuído a Nordau, o escritor "admite a possibilidade do aperfeiçoamento da sociedade, e esta esperança contraria a imputação de pessimismo que se lhe queira fazer: dado o caso de assim denominar-se o outro modo de pensar"..$^{40}$ Ele ironiza, portanto, aqueles que colam no escritor húngaro a pecha de pessimista pelo simples fato de não concordarem com suas opiniões (talvez motivados por um viés demasiado reacionário ou, pelo contrário, revolucionário).

\section{Pessimismo, filosofia e natureza humana}

Não é difícil encontrar entre os críticos assertivas acerca do pessimismo de Raul Pompeia. No entanto, convém atentar para o que o próprio Raul Pompeia escreveu, em 8 de junho de 1889: "não molho a pena no canto do olho, para colher uma lágrima de pessimismo; porque, além do risco de furar o olho, garanto-lhes que traria a pena seca". ${ }^{41}$ Anteriormente, noutra crônica do dia 28 de abril de 1889, Pompeia sustenta ironicamente que "as classes literárias", "de pretenciosas ambições, são expressamente melancólicas. A mocidade letrada acha gosto em ser triste e passar por triste". Não satisfeito e em tom de troça, segue seu raciocínio: “arranja, logo que pode, uma miopia às pressas, que desculpa os óculos precoces, o grave apêndice de senilidade e aros de tartaruga que lhes garante um bom acolhimento entre os velhos..." Afinal, esses jovens literatos "precisam ser sisudos. Amanhã, podem todos vir a ser políticos, mestres e guias da vida social. Precisam ir disciplinando o físico da profissão". ${ }^{42}$ Isso nos conduz à conclusão de que, se há um viés pessimista ou melancólico em suas obras, ele não deve ser buscado na adesão de Pompeia a determinados preceitos literários da época (descritos, como visto, em registro zombeteiro), mas antes, a meu ver, em sua concepção negativa da

\footnotetext{
${ }^{39}$ POMPEIA, Raul. Pandora: Os “paradoxos” de Max Nordau. Gazeta de Notícias, ano XIV, n. 218,6 ago. 1888.

40 Idem.

${ }^{41}$ Idem, A vida na Corte. Diário de Minas, ano II, n. 369, Belo Horizonte, 8 jun. 1889.

42 Idem, ibidem, ano I, n. 300, Belo Horizonte, 28 abr. 1889.
} 
natureza humana (seria no mínimo contraditório conceber alguém como Pompeia, fervoroso republicano e acerbado nacionalista, como melancólico e pessimista).

O pessimismo que a crítica alega existir em suas "canções" se deve, muito provavelmente, aos mal-entendidos quanto às técnicas estilísticas empregadas por Pompeia. Um bom exemplo disso, com relação ao que eu chamo de circularidade interna, está em Marciano Silva, para quem o escritor elaborou uma "concepção evolucionista da História" tensionada por uma "concepção cíclica e decadentista do tempo histórico". ${ }^{43}$ Quando Silva afirma, na mesma página, que é possível encontrar em Canções sem metro uma espécie de “tempo linear do progresso científico e tecnológico interno e subordinado ao tempo circular de nascimento, ascensão, apogeu, decadência e morte das civilizações", ele está parcialmente em sintonia com a noção de circularidade interna. A "parcialidade" se deve à sua interpretação duplamente limitada: primeiro, porque a circularidade não cumpre uma função apenas temporal, mas também estilística e textual; em segundo lugar, se Silva compreendeu o percurso cíclico esboçado por Pompeia (isto é, as fases que vão do nascimento à morte), ele, do meu ponto de vista, remete ao sujeito errado, ou seja, a humanidade ao invés do homem.

O que o levou a cometer o que considero um equívoco hermenêutico foi, sem dúvida, o fato de haver se concentrado na noção de "cataclisma". Ora, tal noção acarreta inevitavelmente o antagonismo entre "utopia" e "degradação", o que, por conseguinte, faz da última opção a mais "concreta", senão a única possível. Em outras palavras, a forma como Silva construiu sua interpretação não poderia produzir outro resultado senão o de concluir pela decadência das civilizações.

Utilizado por Pompeia como uma imagem metafórica pautada na sua visão da natureza humana, o "cataclisma" funciona como uma espécie de ameaça: sendo o homem mau por natureza, naturalmente ele tende antes para a destruição do que para a salvação. O suposto "cataclisma" figura, contudo, como se fosse um plano de fundo em suas "canções", constantemente desautorizado pelo próprio escritor (é o que querem dizer os termos "ilusão renitente", "estranho sonho" etc.), ao mesmo tempo em que confere concretude e efetividade à noção de "ciclo vital humano". Decorre disso que a filosofia de Canções sem metro comporta semelhança com a de Nordau, ao conceber a história como algo ambíguo: se, por um lado, o homem promove o desenvolvimento social, econômico e cultural, por outro, ele também fomenta um cenário em que a "fome é a suprema doutrina" e "consumir é a lei", conforme sugere a "canção" "Ventre". ${ }^{44}$ Pompeia não era, como se pode perceber, contra o progresso; ele questionou os benefícios e prejuízos, reais ou potenciais, advindos

\footnotetext{
43 SILVA, Marciano Lopes e. Decadência das civilizações e memória dos ideais: a filosofia da história na obra de Raul Pompeia, op. cit., p. 203.

44 Ver POMPEIA, Raul. Ventre, op. cit., p. 42. Compare-se essa reflexão com a seguinte proposição de Dostoiévski (1821-1881): “Numa palavra, pode-se dizer tudo da história universal - tudo quanto possa ocorrer à imaginação mais exaltada. Só não se pode dizer o seguinte: que é sensata”. DOSTOIÉVSKI, Fiódor M. Memórias do subsolo. 6. ed. 1. reimpr. São Paulo: Editora 34, 2012, p. 43. Raul Pompeia, leitor das traduções francesas da obra de Dostoiévski, afirmou certa vez que o escritor russo possuía uma "impetuosa intensidade" em sua forma de escrever. POMPEIA, Raul. Pandora: Leituras. Gazeta de Notícias, ano XIV, n. 271,28 set. 1888 .
}

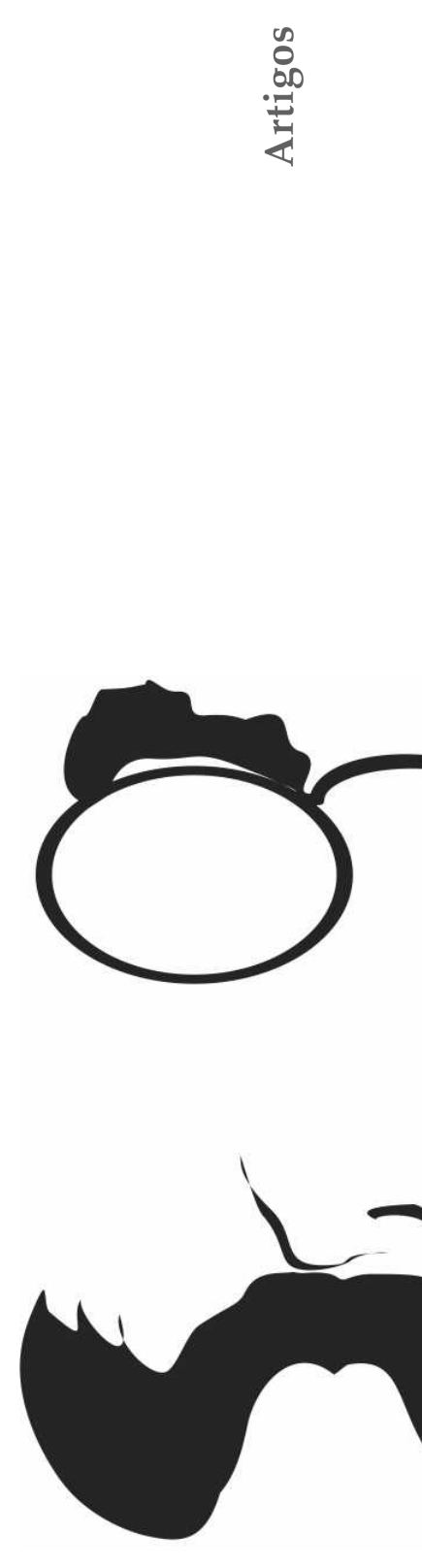


dos maus usos que os homens fazem dos avanços científicos e tecnológicos (do que deriva a noção de "progresso relativo", citada na mencionada crônica 8 de junho de 1889).

Tal interpretação é passível de melhor compreensão quando contrastada com o conto "Correspondências íntimas II": "Eu entendo que o remédio é uma consequência do mal. São dois fatos correlativos e complementares. Mal e remédio, isto é que é a vida. Lutar não é outra coisa senão remediar" ${ }^{45}$ Cabe perguntar o óbvio: remediar o quê? A morte. A última coisa que o escritor pretende transmitir com isso é a ideia de fatalismo frente ao qual nada podemos fazer. Pretende, pelo contrário, fomentar a noção de uma natureza maior, perante a qual somos insignificantes e efêmeros, o que não nos impede de lutar com os recursos de que dispomos (remédios) para retardar o máximo possível o inevitável (a morte). Tal concepção se resume na seguinte proposição: a morte para o homem, o "cataclisma", para a humanidade; certeza para o primeiro, incerteza para o segundo. Por essa lógica, se a morte é incontornável para o homem, ela não o é para a humanidade. E é justamente isso o que possibilita o incremento das conquistas angariadas pelas gerações anteriores, como representado por cada novo ciclo que se reinicia.

Nos seus textos filosoficamente mais bem-acabados, as referências ao ciclo vital, ao "progresso relativo" e ao embate entre o homem e a natureza constituem temas recorrentes. Em algumas "canções" (que não constam na edição de 1900), essa temática frequentemente aparece sob a forma da "esperança". É o caso de "A bandeira branca", "Frutos verdes", "Hebe imortal", "Lágrimas da Terra" e "O ramo da esperança". ${ }^{46}$ Há, no entanto, dois outros textos de difícil classificação (que prefiro chamar de meditações) nos quais o escritor aborda os mesmos assuntos: "Cavaleiros andantes" e "Cartas ao futuro" (este em publicação póstuma). Em "Cavaleiros andantes" 47 , por exemplo, ao meditar sobre as relações entre a humanidade e suas religiões - que, à medida que envelhecem, são substituídas por outras, como indica a epígrafe de “Os deuses" 48 -, Pompeia sugere que o Deus característico do século XIX, que já não é tão metafísico quanto os anteriores, embora seja mais opressivo e cruel, não é outro senão uma criação humana por excelência: a indústria. Já o texto "Cartas ao futuro" pode ser entendido como uma sequência da dialética decadência/evolução: “o turbilhão universal é uma série gradual de fases e aspectos, o tempo é uma série de sucessos ininterrompidas em movimento perpétuo". Para Pompeia, as "obras geniais da arte, os esforços geniais da ciência são outros tantos desmascaramentos da hipocrisia falaz da natureza", desmascaramento pelo qual "o gênio desmoraliza o mundo", mesmo consciente de que "o mundo não quer ser desmentido", pois sua dissimulação é necessária, dado que a "natureza pretende esmagar a humanidade, sem que ela compreenda o esmagamento". ${ }^{49}$

\footnotetext{
${ }^{45}$ Idem, Correspondências íntimas II. In: Contos. Biblioteca Digital de Literaturas de Língua Portuguesa: UFSC. Disponível em <https://www.literaturabrasileira.ufsc.br/?locale=pt_BR>. Acesso em 21 maio 2019.

${ }^{46}$ Ver idem, Canções sem metro. Organização, introdução e notas de Gilberto Araújo op. cit.

${ }^{47}$ Ver idem, Cavaleiros andantes. In: Contos. op. cit. s/p.

${ }^{48}$ Ver idem, Canções sem metro, op. cit., p. 70. Trata-se de uma citação de El diablo mundo, de José de Espronceda, na qual se lê: "Las criencias que abandonas, / Los templos, las religiones/ Que pasaron, y que luego/ Por mentira reconoees,/ Son. quizd, menos mentiral Que las que ahora te forges?"

${ }^{49}$ Idem, Cartas ao futuro. Gazeta da Tarde, ano XVIII, n. 169, 27 dez. 1897, p. 1.
} 
Em outras palavras, o que Pompeia tenciona explicitar é a insignificância do ser humano perante a natureza, se bem que não retire dele, em ambos os casos, a possibilidade de conquistá-la, nunca completamente, e sim aos poucos e conforme as circunstâncias: "aproveitando-se do trabalho destes gigantes insurgidos contra o Olimpo das forças misteriosas do mundo, a humanidade conhece melhor o universo e melhor compreende sua miséria", ele salienta em "Cartas ao futuro". Mas, se é verdade que "o homem nasce para morrer, unicamente para morrer; e cada expansão da vida é a reclamação enérgica deste banal destino", nem por isso o autor sustenta a existência de um fatalismo inevitável, uma vez que "transformar, transformar é a lei: é preciso que deixemos aos outros a ribalta, por onde passamos a representar a triste comédia da matéria". Da luz presente nessa ribalta encarregam-se a arte e a ciência (na linha de sua narrativa em "Cartas ao futuro", se até mesmo "o gênio padece no mundo", sua obra, entretanto, fica-nos como prova do seu legado, para melhor "guiarmo-nos"). ${ }^{50}$ Tem-se aqui, portanto, outra alusão à supremacia da arte.

É com base nesse raciocínio que considero "Conclusão" como uma "canção" que finaliza não somente a quinta parte do livro, mas ele como um todo: parafraseando um grande cataclisma (dilúvio), Raul Pompeia escreve que, passada a tormenta, findo o ciclo, "torna também o firmamento à limpidez da bonança. Ao mar, aos homens, reapareceu, sem mácula, a amplidão do azul". E reforça: "Sem mácula!", sem deixar de alertar que "pode vir de novo a coorte dos nimbos travar o drama da tempestade. Pode vir a estrela e prosseguir a jornada nômade que leva". ${ }^{51}$ Convém destacar que esse mesmo cenário já havia sido descrito na segunda parte de Canções sem metro, mais precisamente em "Ilusão renitente", acentuando que a imagem catastrófica nada mais era do que um "estranho sonho", assim como há a certeza exemplificada pela personagem que desperta da letargia ao ver a "luz de um olhar" - de que "nem tudo perecera". ${ }^{52}$ Logo, a noção reincidente do "cataclisma" serve para corroborar uma dupla mensagem, ao ressaltar a insignificância do ser humano perante as forças da natureza para, em seguida, aludir ao caminho naturalmente autodestrutivo que os homens tendem a trilhar, embora seja possível evitá-lo (posto que alertados). É por isso que Pompeia apresenta como solução ao problema hipotético do "cataclisma" justamente a oportunidade real de reiniciar o ciclo da vida (sem se esquecer da cumulatividade dos ciclos anteriores).

Esse reinício é expresso, no seu modo mais bem-acabado, na segunda parte do livro, intitulada Amar, recorrendo a alusões, metáforas e alegorias: a primavera equivale à juventude, o verão, ao início da vida adulta, o outono, ao amadurecimento humano e o inverno, à morte. Cada estação e fase é intrínseca à própria natureza, fugindo, portanto, ao controle humano. $\mathrm{O}$ fator da cumulatividade, representado pelo patrimônio científico e artístico da humanidade, constitui uma herança dos ciclos anteriores aos sucessivos ciclos vindouros. O que precede e embasa essas considerações é a concepção que Raul Pompeia tinha da natureza humana. Sobre tal aspecto, impõem-se alguns es-

\footnotetext{
${ }^{50}$ Idem.

${ }^{51}$ Idem, Canções sem metro, op. cit., p. 76.

${ }^{52}$ Idem, ibidem, p. 27.
} 
clarecimentos. Para esse fim, "Os animais" (com a sugestiva epígrafe de Gênesis 1:26) é uma "canção" que serve melhor do que qualquer outra. ${ }^{33}$ Escrito como um simulacro da criação bíblica do homem, nesse poema em prosa Pompeia visa recriar alguns elementos da natureza humana supostamente negligenciados no relato de Gênesis, o que é feito via comparação homem versus animal.

Após o preâmbulo - "Vosso rei! proferiu Jeová, entregando o Homem à criação" -, a "canção" continua: "A imagem de argila acordou pouco a pouco num frêmito de vida que lhe percorreu suavemente os membros. O olhar do homem abriu-se claro, infantil e nobre. Era ainda a majestade cândida do olhar dos anjos". Registre-se que, na sua origem, o homem é bom, tal como um "anjo". A própria natureza lhe seria totalmente submissa e acolhedora, tal como no "paraíso": "Para dar caminho ao Rei", isto é, ao homem, "abriram-se dóceis os penhascos; as franças debruçaram-se, formando grinaldas festivas em arcarias triunfais", e "irromperam em pressa dos cálices as pétalas das flores, como lábios, para sorrir-lhe aos pés - matizaram a relva, os prados, em grande gala". A corrupção do homem inicia-se, porém, com a "chegada dos animais", quando "cada qual ofertou ao Homem, em tributo, o que julgava a melhor das dádivas do Criador" (atente-se para a ironia que recobre os adjetivos malícia, vileza, traição, luxúria etc., tidos como "o melhor das dádivas" concedidas por Deus, o que, no fundo, coloca em dúvida a própria natureza divina):

Veio a águia e ofereceu as asas e os estímulos elevados; o leão ofereceu a juba arrogante e a majestade selvagem; o tigre ofereceu as garras e a sede de sangue; o elefante, a força colossal; o símio, a malícia; a raposa, a sagacidade; a serpente, o veneno e as linhas curvas; o cão, a leal vileza; a hiena, os instintos da traição; o asno, a perseverança; o cavalo, o dorso e a celeridade; o avestruz, o poderoso estômago e a cobiça; o bode, a luxúria; o porco, o próprio ventre e a torpeza; o pombo a alvura das penas; o cisne, o derradeiro canto; o pavão, a vaidade; o rato, a rapacidade - perícia prática do instinto. ${ }^{54}$

Mais significativo é o seu desfecho: "O Rei apossou-se de tudo. Estava transformado o anjo de argila. E a natureza unânime aclamou esse monstro". Como se percebe, a concepção que Raul Pompeia tinha do ser humano é a matriz de toda sua filosofia. Tal concepção, todavia, não era exclusividade dele. Sem a intenção de efetuar uma análise comparada, e limitando-nos unicamente a uma exemplificação, examinemos, por exemplo, um trecho de $\mathrm{Me}$ mórias do sobsolo, de Fiódor Dostoiévski: "Penso até que a melhor definição do homem seja: um bípede ingrato. Mas isto ainda não é tudo, ainda não é tudo, ainda não é o seu maior defeito; o seu maior defeito é a sua permanente imoralidade" ${ }^{55} \mathrm{~A}$ semelhança é inegável. No entanto, se, por um lado, predomina

\footnotetext{
${ }^{53}$ Ver idem, ibidem, p. 35 e 36. A epígrafe, no original em latim, é seguinte: “Aí Ele [Deus] disse: - Agora vamos fazer os seres humanos, que serão como nós, que se parecerão conosco. Eles terão poder sobre os peixes, sobre as aves, sobre os animais domésticos e selvagens e sobre os animais que se arrastam pelo chão" (Gênesis, 1:26). Cf. Gênesis. In.: Bíblia Sagrada. Sociedade Bíblica do Brasil. Disponível <em https://www.sbb.org.br/>. Acesso em 18 set. 2020.

${ }^{54} \mathrm{Idem}$.

${ }^{55}$ DOSTOIÉVSKI, Fiódor M., op. cit., p. 42.
} 
essa filosofia negativa, por outro, a redenção está presente em ambos os escritores, e de maneira assaz semelhante: em Pompeia, com o início de um novo ciclo (o nascimento sem mácula); em Dostoiévski igualmente com o nascimento de uma criança (sem máculas) que faz com que a personagem-narrador formule a seguinte reflexão: "Mas não está nisso toda a felicidade, quando ficam juntos os três - o marido, a mulher e o filho? Em troca de momentos como este, muita coisa se pode perdoar". ${ }^{56}$

Mesmo aqui, em um cenário que está longe de ser um "mundo feliz de Pangloss", não há nada que impeça a "esperançada da corrigenda", marcada nas duas situações pelo recomeço da vida, por uma nova possibilidade. ${ }^{57}$ Devido ao caráter duplamente cíclico da formulação de Pompeia, isto é, temporal e metafórico, de um lado, e textual e estilístico, de outro, não há como conceber, a exemplo de Silva ${ }^{58}$, que exista alguma espécie de "apelo revolucionário" no autor, nem tampouco a expressão de uma total decadência das civilizações. Sua concepção da natureza humana, confundida erroneamente com um pessimismo de extração vulgar, desautoriza medidas extremas, ao passo que em momento algum é negada a possibilidade de que a humanidade se aperfeiçoe a cada novo ciclo vital. O próprio ciclo representa a possibilidade efetiva da crença em um futuro melhor, guiado, por sua vez, pelas conquistas daqueles que se insurgiram através da arte e da ciência contra a natureza (seja ela física ou humana). Daí a noção de "progresso relativo" que, à maneira de Nordau, expressa a ambiguidade da evolução histórica da humanidade (sem que Pompeia seja por isso evolucionista).

Portanto, Canções sem metro é uma obra que permite vislumbrar uma concepção invariavelmente negativa do ser humano, mas em cuja origem encontra-se a própria essência deste, que seria mau por natureza. Decorre dessa concepção que os avanços científicos e tecnológicos seriam "maculados" por tal natureza, já que engendrados por ela. A descrença na bondade natural, o que impossibilitaria utopias (mas não "cataclismas"), constitui um fenômeno recorrente em toda a produção de Raul Pompeia (romances, contos, crônicas). Nisso não se manifesta nenhuma contradição: primeiro, porque, se o homem é essencialmente mau, nem por isso ele deixa de praticar boas ações, como sugere a "canção" "Primavera"; segundo, porque a evolução histórica da humanidade, a despeito de sua ambiguidade, está inserida em um plano maior, caracterizado por um progressivo controle do homem sobre a natureza. À vista disso, não se trata de pessimismo, fatalismo e muito menos de conformismo; antes, de um incentivo à perseverança. O que nem sempre favoreceu essa compreensão foi a forma empregada por Pompeia para incentivar metaforicamente os homens: para ele, em vez de nos espelharmos no "paraíso" como meta, devemos nos ater à ameaça do pior, ou seja, ao espectro do "cataclisma" (sempre mais próximo de nós do que o primeiro).

De fato, como evidencia a intenção do escritor, apesar da morte ser algo contra o qual nada se pode fazer senão remediar, ainda assim ela não impossibilita a vida (sem a qual sequer existiria), como tampouco impossibilita

\footnotetext{
${ }^{56}$ Idem, ibidem, p. 113.

${ }^{57}$ Reflexão semelhante é proposta por João Cabral de Melo Neto. Ver MELO NETO, João Cabral. Morte e vida severina. Rio de Janeiro: Alfaguara, 2016.

${ }^{58}$ Ver SILVA, Marciano Lopes e. Raul Pompeia: impasses de um formalista avant la lettre, op. cit.
} 
que novas vidas nasçam das já existentes, reiniciando o ciclo vital. Essa é a filosofia de Canções sem metro, e seu ideal, a "esperança". Pompeia era, por esse ângulo, o que se pode chamar de visionário. Por fim, resta dizer que, estilisticamente, ao analisarmos suas "canções", fica também evidente a maestria com a qual ele abordou temas que considerava filosoficamente relevantes, politicamente decisivos e artisticamente respeitáveis, o que atesta seu diversificado e apurado programa estilístico. Como disse Higino, nele a "paixão inventiva é tanto do criador literário como do filósofo. Um e outro inventam coisas com o pensar". ${ }^{59}$

Artigo recebido em 18 de setembro de 2020. Aprovado em 11 de novembro de 2020.

\footnotetext{
${ }^{59}$ HIGINO, Nuno. Entre filosofia e literatura: responsabilidade infinita. Revista Humanística e Teologia, v. 32,
} n. 2, Porto, jul.-dez. 2011, p. 74. 